\title{
УДК 811.124'367.32'373.612.2:821-1(37)
}

\section{МАРКЕРИ ПРЯМОЇ МОВИ У РИМСЬКІЙ ПОЕЗІЇ ЕПОХИ АВГУСТА (на матеріалі "Метаморфоз" Овідія)}

\author{
Чернюх Богдан Васильович (м. Львів, Украӥна) \\ cherboh@gmail.com
}

\begin{abstract}
доктор філол. наук, професор, завідувач кафедри класичної філологіі Львівський наиіональний університет імені Івана Франка
\end{abstract}

Аналіз засобів впровадження прямої мови у поемі Овідія «Метаморфози» дозволяє виділити три групи: дієслова мовлення, іменні фрази та еліптичні конструкиіі. Основними маркерами прямої мови виступають дієслова мовлення, серед яких виділяються гіпероніми (dico, aio, inquam, fari), щуо констатують сам факт говоріння, та гіпоніми, які характеризуються додатковим семантичними відтінками (сlaто, loquоr тощо). Найчастіше пряму мову впроваджують гіпероніми, особливо dico, тоді як аіо та іпqиат займають друге і третє місие. Мінімальною частотністю характеризується fari та його композити (adfari, profari). Доволі поширеними є також іменні фрази, до складу яких входять іменники з семантикою мовлення (напр., ora solvere, voces dare). Поодиноко у «Метаморфозах» представлені еліптичні конструкиії (напр., talibus genitor, tumilla тощьо) притаманні для діалогів. Місие маркерів стосовно прямої мови може варіюватись, проте найчастіме, на відміну від прози, вони представлені в інтрапозиції, щзо зумовлюється особливостями поетичного синтаксису. Особливо притаманною інтрапозиція є для іпqиат. Характерним також є те, щчо дієсловагіпоніми та інші маркери прямої мови здебільшого представлені у препозиції.

Ключові слова: латинська мова, римська поезія, Овідій, пряма мова, дієслово, іменна фраза.

Актуальні проблеми мовознавства [Актуальные проблемы языкознания] (C) Чернюх Б. В. [Чернюх Б. В.], cherboh@gmail.com Маркери прямої мови у римській поезії епохи Августа (на матеріалі "Метаморфоз" Овідія) [Маркеры прямой речи в римской поэзии эпохи Августа (на материале «Метаморфоз» Овидия)] 


\title{
МАРКЕРЫ ПРЯМОЙ РЕЧИ В РИМСКОЙ ПОЭЗИИ ЭПОХИ АВГУСТА (на материале «Метаморфоз» Овидия)
}

\author{
Чернюх Богдан Васильевич (2. Львов, Украина) \\ cherboh@gmail.com \\ доктор филол. наук, профессор, \\ заведуюший кафедрой классической филологии \\ Львовский национальный университет имени Ивана Франко
}

\begin{abstract}
Анализ средств введения прямой речи в поэме Овидия «Метаморфозы» позволяет вылелить три группь: глаголь речи, именные словосочетания $и$ эллиптические конструкции. Основными маркерами прямой речи выступают глаголь речи, среди которых выделяются гиперонимы (dico, aio,inquam, fari), обозначающие сам факт говорения, и гипонимы, которым свойственнь дополнительные смысловые оттенки (сlато, lоqиоти т. п.). Чаме всего прямую речь вводят гиперонимы, особенно dico, тогда как аіо и inquат занимают, соответственно, второе и третье место. Наименее употребительным в данной группе является fari $u$ его композить (adfari, profari). Довольно распространенными являются также именные словосочетания, в состав которых входят существительные с семантикой речевой деятельности (напр., ora solvere, voces dare). Единичными случаями в «Метаморфозах» представлень эллиптические конструкции (напр., talibus genitor, tumilla) свойственные для диалогов. Место маркеров относительно прямой речи может варьироваться, однако наиболее распространенным, в отличие от прозы, они представлены в интрапозиции, что обусловлено особенностями поэтического синтаксиса. Особенно характерна интрапозиция для іпqиат. В то же время, для гипонимов и иных маркеров прямой речи преимущественно свойственно препозитивное употребление.
\end{abstract}

Ключевые слова: латинский язык, римская поэзия, Овидий, прямая речь, глагол, именная фраза.

Actual Problems of Linguistics [Aktual'ni problemy movoznavstva] (C)Cherniukh B. V. [Chernjuh B.V.], cherboh@gmail.com Markers of the Direct Speech in Roman Poetry of the Augustan Period (on "Metamorphoses" by Ovid) [Markery prjamoi' movy u ryms'kij poezii' epohy Avgusta (na materiali "Metamorfoz" Ovidija)] (in Ukrainian) 


\title{
MARKERS OF THE DIRECT SPEECH IN ROMAN POETRY OF THE AUGUSTAN PERIOD (ON “METAMORPHOSES” BY OVID)
}

\author{
Cherniukh Bohdan Vasylovych (Lviv, Ukraine) \\ cherboh@gmail.com
}

\begin{abstract}
Doctor of Philology, Professor, Head of the Department of Classical Philology Ivan Franko National University of Lviv
\end{abstract}

The analysis of the means of introducing direct speech in Ovid's poem "Metamorphoses" makes it possible to distinguish three groups: speech verbs, noun phrases and elliptical constructions. The main markers of direct speech are speech verbs divided into hyperonyms (dico, aio, inquam, fari) denoting bare fact of speaking, and hyponyms with additional semantic shade. Among them, the most common are hyperonyms, especially dico, while aio and inquam are second and third respectively. The minimum frequency is shown by fari and its composites (adfari, profari). Noun phrases that include nouns with semantics of speech (e.g, ora solvere, voces dare) are on the second place as to their frequency. Alone in "Metamorphoses", elliptical constructions (e.g, talibus genitor, tum illa, etc.) are inherent in dialogues. The place of markers regarding direct language may vary, but most often, unlike prose, they are intraposed, which is conditioned by the peculiarities of poetic syntax. Particularly characteristic intraposition is for inquam. Unlike hyperonyms, hyponyms as well as other means of introducing direct speech are usually preposed.

Keywords: Latin, Roman poetry, Ovid, direct speech, verb, noun phrase.

У представленій статті розглянуто засоби впровадження прямої мови у латинській поезії доби Августа на матеріалі «Метаморфоз» Овідія.

Відмінність між відтворенням реальності та іiі зображенням відзначав вже Платон (Rep. 3, 392-395), розрізняючи mimēsis безпосередне відтворення або імітацію подій та diēgēsis - їx узагальнене відтворення, тим самим заклавши підвалини до диференціації прямої і непрямої мови, яка вже тривалий час є об'єктом дослідження різних галузей лінгвістики: дискурсного аналізу, стилістики, прагматики, когнітивної та історичної лінгвістики, функціональної граматики, мовної типології, синтаксису і семантики (детальніше про це [Bonami, Godard 2008; Buchstaller 2014, p. 36; Capone 2013]) .

Актуальні проблеми мовознавства [Актуальные проблемы языкознания] (C) Чернюх Б. В. [Чернюх Б. В.], cherboh@gmail.com Маркери прямої мови у римській поезії епохи Августа (на матеріалі "Метаморфоз" Овідія) [Маркеры прямой речи в римской поэзии эпохи Августа (на материале «Метаморфоз» Овидия)]

(Українською / На укр. яз.) 
Переважно чужа мова, їі різновиди (пряма, непряма, невласне пряма мова) та засоби впровадження аналізується на матеріалі сучасних мов, напр., [Buchstaller 2014; Güldemann 2008]. В латиністиці об'єктом дослідження переважно була і залишається непряма мова та невласне пряма мова, для яких властива транспозиція особи, часу, способу. Пряма ж мова, будучи позбавленою особливих рис і розглядаючись здебільшого у зв'язку з непрямою [Ваños Baños 2009, p. 733-758; Sznajder 2002, p. 361377], не привертала особливої уваги, залишаючись на маргінесі i трактуючись негативно у порівнянні 3 останньою. Цим, вочевидь, зумовлена порівняно невелика кількість досліджень зі згаданої проблематики. Водночас варто відзначити, що останнім часом оцінка прямої мови змінилось, оскільки вона, як відзначає Г. Розен [Rosén 2013, p. 255], характеризується не лише негативно 3 огляду на відсутність транспозиції особи, способу, часу, але й позитивно завдяки значній кількості екстрапропозиційних ознак (вигуків, звертань тощо). Це стимулювало інтерес дослідників до неї і вилилось у появу низки статей [Gayno, 2015; Mikulová 2015; Mikulová 2016; Mikulová 2018; Sznajder 2015; Thomas 2015].

Прийняте у даній статті розуміння прямої мови опирається на тезу про притаманність для неї двох дейктичних центрів - мовця і оповідача на противагу до непрямої, для якої властивий лише один дейктичний центр оповідач [Güldemann 2008, p. 8; Keizer 2009, p. 847; Sznajder 2002, p. 381; Vandelanotte 2004, p. 490-491].

Пряма мова не лише передбачає позицію мовця, а й, будучи засобом передачі певного повідомлення, виконує репортативну функцію. 3 огляду на це висловлювання типу “роман «Війна і мир» або “хвороба Паркінсона”, які М. де Вріз, зараховує до прямої мови, характеризуючи як «включену пряму мову» (embedded direct speech) [de Vries 2008, p. 50-54], не розглядаються тут як пряма мова sensustricto. Також у представленій статті до уваги не береться невласне пряма мова, яка, займаючи проміжне місце між прямою i непрямою, характеризується особливостями у вживанні часу, способу, особи тощо.

Інкорпорація прямої мови у дискурс може відбуватись різними способами. Одним з найпоширеніших $є$ ії впровадження за допомогою т. зв. «маркерів цитування». Такі маркери характеризуються серйозним

Actual Problems of Linguistics [Aktual'ni problemy movoznavstva] (C)Cherniukh B. V. [Chernjuh B.V.], cherboh@gmail.com Markers of the Direct Speech in Roman Poetry of the Augustan Period (on "Metamorphoses" by Ovid) [Markery prjamoi' movy u ryms'kij poezii' epohy Avgusta (na materiali "Metamorfoz" Ovidija)] (in Ukrainian) 
прагматичним потенціалом, оскільки впливають на емоції читача і на його сприймання описуваних подій. Вони мають двояку спрямованість, 3 одного боку впроваджують і пояснюють пряму мову, а 3 іншого, як складова дискурсу, виконують прагматичну функцію, оскільки не лише вказують на адресата прямої мови, а й містять іï опис і факультативно можуть включати характеристику адресата, манеру виголошення та обставини, які супроводжують мовлення. Окрім того, одна із функцій маркерів прямої мови полягає у ідентифікації мовців та структуруванні дискурсу. Це, особливо важливе за відсутності візуальних засобів позначення прямої мови (двокрапки, лапок тощо), які ввійшли у вжиток 3 появою друкарства [Sznajder 2015, p. 1].

Серед таких вербальних маркерів вагоме місце належить дієсловам, пов'язаним із комунікацією (verba dicendi). При цьому йдеться не лише про типові дієслова мовлення на зразок «говорити», а й про інші, які відрізняються від нього відтінками значень (кричати, співати, шепотіти тощо) і навіть ті, що належать до інших семантичних груп. Принагідно варто відзначити, що саме verba dicendi $\epsilon$ домінантними засобами впровадження прямої мови в аналізованому творі.

Незважаючи на свою поширеність, дієслова є лише одним, i, як свідчать типологічні дослідження [Buchstaller 2014, p. 41; Güldemann 2002, p. 283], не найпоширенішим засобом впровадження прямої мови. Окрім них вказувати на неї можуть інші лексичні одиниці, а також інтонація, просодика, контекст, пунктуація.

Деякі із лексичних маркерів прямої мови 3 плином часу могли зазнавати граматизації, характерними ознаками якої є десемантизація, розширення використання у новому контексті, декатегоризація, ерозія (фонетична редукція) [Heine 2003, p. 579; Klamer 2000, p. 69-98]. Добре описана у літературі, напр., [Golato 2000; Fruyt 2015; Romaine, Lange 1991; Vandelanotte 2012], граматизація є індивідуальною для кожної мови як щодо залучення різних частин мови (найпридатнішими для цього є частки і прислівники), так і щодо свого характеру (повна чи часткова).

Домінуючим засобом впровадження прямої мови у «Метаморфозах» $\epsilon$ дієслова у особових і неособових формах. Із 522 випадків вживання пряма мова 482 рази (92\%) впроваджується саме дієсловами. У

Актуальні проблеми мовознавства [Актуальные проблемы языкознания] (C) Чернюх Б. В. [Чернюх Б. В.], cherboh@gmail.com Маркери прямої мови у римській поезії епохи Августа (на матеріалі "Метаморфоз" Овідія) [Маркеры прямой речи в римской поэзии эпохи Августа (на материале «Метаморфоз» Овидия)] (Українською / На укр. яз.) 
34 випадках (7\%) іiі впроваджують іменники пов'язані 3 процесом мовлення (verbum, vox, os, querella, cantus, dictum) у поєднанні з дієсловом, напр.: ora solvit (Ov. Met. 1, 182), addidit verba (Ov. Met. 3, 191), committit voce (Ov. Met. 5, 307). Зрідка (6 фіксацій, 2 \%) пряма мова впроваджується без допомоги дієслова. Сюди належать вирази sic Aesonides (Ov. Met. 7, 164 ), Aeacides illi (Ov. Met. 11, 379), tum senior (Ov. Met. 12, 182), at illa (Ov. Met. 11, 622), ad haec Pylius (Ov. Met. 12, 542), talibus genitor (Ov. Met. 15, 807) та контекст. Вони особливо характерні для діалогів, утворюючи конструкції на зразок: «Х сказав ..., а Ү (відповів)», і виникли внаслідок еліпсису дієслова мовлення.

Серед виключно дієслівних засобів впровадження прямої мови виділяються дві групи: 1) гіпероніми - дієслова, у яких сема «мовлення» представлена у чистому вигляді (dico, inquam, aio, fari); 2) гіпоніми дієслова $з$ додатковими семантичними відтінками (respondeo, clamo, voco, loquor тощо).

Усі дієслівні маркери прямої мови, незалежно від їх статусу, у подальшому характеризуватимуться як дієслова мовлення, хоч деякі дослідники диференціюють ї. Зокрема, Г. Дойчер виокремлює «дієслова мовлення» (speech verbs, напр., 'say') та «дієслова, які стосуються мовлення» (speech related verbs, напр., 'write') [Deutscher 2001, p. 647, 652]. Подібна точка зору представлена у Т. Гюльдемана, який диференціює загальні і специфічні дієслова мовлення (generic speech verbs/specific speech verbs), слушно зауважуючи, що у контексті прямої мови дієсловами мовлення можуть вважатись й інші дієслова, позбавлені у своєму прямому значення семи «мовлення» [Güldemann 2008, p. 12].

Місце маркерів стосовно прямої мови може варіюватись. Згідно 3 Т. Гюльдеманом, можливою є їх препозиція, постпозиція, ціркумпозиція та інтрапозиція, а також поєднання цих типів [Güldemann. 2008, p. 192].

На противагу до латинської прози, для якої характерне препозитивне розташування засобів впровадження прямої мови [Mikulová 2016, p. 170; Mikulová 2018, p. 205], у аналізованому тексті вони переважно перебувають у інтрапозиції (268 випадків, $51 \%$ ); майже вдвічі рідше представлена препозиція (117 випадків, 23 \%) та постпозиція (97 випадків, $19 \%$ ). Іноді засвідчена ціркумпозиція (препозиція-постпозиція) (12 випадків, 2 \%) та інтрапозиція-постпозиція (28 випадків, 5 \%). Це може

Actual Problems of Linguistics [Aktual'ni problemy movoznavstva] (C)Cherniukh B. V. [Chernjuh B.V.], cherboh@gmail.com Markers of the Direct Speech in Roman Poetry of the Augustan Period (on "Metamorphoses" by Ovid) [Markery prjamoi' movy u ryms'kij poezii' epohy Avgusta (na materiali "Metamorfoz" Ovidija)] (in Ukrainian) 
зумовлюватись як особливостями дієслів (inquam, наприклад, переважно представлене у інтрапозиції), так і метричними вимогами.

Розглянувши у загальних рисах засоби впровадження прямої мови у аналізованих творах, перейдемо до опису окремих груп.

\section{1. Гіпероніми}

Як згадувалось вище, гіпероніми представлені дієсловами, які номінують процес мовлення i позбавлені додаткових семантичних відтінків. Ця група представлена дієсловами dico, aio, inquam та fari, які домінують серед інших маркерів прямої мови.

\subsection{Dico.}

Dicere $€$ найпоширенішим засобом впровадження прямої мови у «Метаморфозах», де представлене 204 фіксаціями (51 \%). Переважно воно вживається у особових формах (197 випадків). Неособові форми (7 випадків) представлені infinitivus perfecti та part. praes. act. Серед фінітних форм переважає perfectum indicativi - 161 випадок та plusquamperfectum indicativi - 28 випадків, решта представлені поодиноко. У «Метаморфозах» dicere переважно займає серединну і кінцеву позицію 110 випадків інтрапозиції та 80 випадків постпозиції проти 14 випадків препозиції.

Окрім зазначеного розташування стосовно прямої мови dicere часто виступає як другий компонент у ціркумпозиції (ait ... dixit (Ov. Met. 2, 426428), adfatur ... dixerat (Ov. Met. 1, 350-367), або поєднується із іншим дієсловом мовлення, яке перебуває у інтрапозиції (... ait ... dixit (Ov. Met. 5, 224-230), ... dixit ... dixerat (Ov. Met. 11, 585-589), ... inquit ... dixit (Ov. Met. 13, 445-449), так що два verba dicendi утворюють рамкову конструкцію.

\subsection{Aio}

Серед дієслів, які впроваджують пряму мову, aio $є$ другим за частотою вживання і представлене 127 разів. Всюди воно представлене формою ait, займаючи різне положення стосовно прямої мови, проте переважно представлене у інтрапозиції (86 випадків, 69 \%). Препозитивне та постпозитивне вживання цього дієслова представлене приблизно порівну: 20 випадків препозиції, 19 - постпозиції. Виступаючи на початку

Актуальні проблеми мовознавства [Актуальные проблемы языкознания] (C) Чернюх Б. В. [Чернюх Б. В.], cherboh@gmail.com Маркери прямої мови у римській поезії епохи Августа (на матеріалі "Метаморфоз" Овідія) [Маркеры прямой речи в римской поэзии эпохи Августа (на материале «Метаморфоз» Овидия)] 
або в середині прямої мови, аіо може поєднуватись 3 іншими дієсловами мовлення, переважно із dicere, які займають кінцеве положення.

\subsection{Inquam}

Маркер inquit виявлений у 73 випадках. Окрім згаданої форми у «Метаморфозах» тричі засвідчено inquam. Переважно це дієслово представлене у інтрапозиції (64 випадки, 88 \%). Постпозиція зафіксована у 9 випадках (12\%). На відміну від dico та aio, які здатні приєднувати всі можливі види пропозитивних актантів: пряму мову, інфінітивні звороти, вставні речення 3 ut, це дієслово впроваджує виключно пряму мову. Приблизно у третині випадків inquit поєднується 3 іншим дієсловом (переважно dicere), яке замикає пряму мову.

Впроваджуючи пряму мову, згадане дієслово іноді поєднується із іншими засобами, які перебувають у препозиції. Подібні випадки $\epsilon$ нечисленними (всього 6 фіксацій). У трьох випадках inquit поєднується 3 дієсловами мовлення, які належать до групи гіпонімів (rogare, increpare, monere), стосуються одного й того ж суб'єкта і впроваджують одну й ту ж пряму мову, напр., ... rogat “...”” Inquit “...” (Ov. Met. 1, 734-737), monet “...” inquit “...” (Ov. Met. 10, 543-544)

Окрім того inquit, яке перебуває у інтрапозиції, іноді поєднується 3 займенниками або прийменниковими конструкціями, що стоять на початку прямої мови і характерні для діалогічних партій, напр., cui “...” inquit “...” (Ov. Met. 8, 405-406), ... adhos “...” inquit “...” (Ov. Met. 15, 610).

Незначна, порівняно 3 пізньою латиною [Mikulova 2015, p. 131], кількість випадків поєднання inquit з іншими маркерами прямої мови може свідчити про те, що у класичній латині це дієслово вже перебуває на початковій стадії граматизації [Güldemann 2008, p. 198], яка характеризується обмеженими функціональними можливостями при збереженні базової семантики [Kieckers 1919, p. 200].

\subsection{Fari ta composita}

До аналізованої групи дієслів належить також fari. У «Метаморфозах» воно перебуває на периферії, зустрічаючись лише у 5 випадках. На противагу до dico, aio та inquam, які однаковою мірою представлені у поезії та прозі, fari $є$ ознакою поетичної мови, що підтверджується його відсутністю у прозі класичного періоду, де поодиноко засвідчений аблатив герундія fando.

Actual Problems of Linguistics [Aktual'ni problemy movoznavstva] (C)Cherniukh B. V. [Chernjuh B.V.], cherboh@gmail.com Markers of the Direct Speech in Roman Poetry of the Augustan Period (on "Metamorphoses" by Ovid) [Markery prjamoi' movy u ryms'kij poezii' epohy Avgusta (na materiali "Metamorfoz" Ovidija)] 
У аналізованому творі fari переважно виступає у формах fatur та fatus. Плюсквамперфект (fatus erat) засвідчений двічі. Впроваджуючи пряму мову, згадане дієслово перебуває у пре- і постпозиції, при цьому переважає його постпозитивне вживання. При цьому характерним є те, що у постпозитивному вживанні переважно засвідчений participium perfecti. У «Метаморфозах» препозиція fari представлена двома випадками, постпозиція -трьома.

Поряд із fari в аналізованому творі засвідчено композити adfari та profari, яким префікси надають додаткових аспектуальних відтінків початку (adfari) та продовження (profari). Як видається, саме аспектуальна i локативна семантика префіксів i спричинена ними модифікація лексичного значення зумовлює передування цих дієслів прямій мові i наявність співрозмовника, до якого скеровані слова персонажа.

\section{2. Гіпоніми}

Як згадувалось вище, до цієї групи належать дієслова, у яких сема «говоріння» доповнюється додатковими семантичними відтінками. Дана група є гетерогенною і окрім verba dicendi також охоплює дієслова, які отримують згадане значення у відповідному контексті, напр., вжите зі значенням «відповідати» refero. Загалом у «Метаморфозах» представлено 15 таких дієслів вжитих у 67 контекстах. Найширше представлені дієслова clamo - 16 фіксацій, exclamo - 14 фіксацій, refero - 12 фіксацій, adloquor 5 фіксацій, loquor - 4 фіксації. Частотність вживання решти дієслів (impero, rogo, blandior, voco, vaticinor, conclamo, cano, oro) не перевищує двох раз. Крім дієслів безпосередньо пов'язаних з процесом мовлення тут представлені й інші, які у контексті наближаються до них, наприклад, signare, як у наступному випадку: Naides ... // corpora dant tumulo, signant quoque carmine saxum: // HIC SITVS EST PHAETHON CVRRVS AVRIGA PATERNI ... (Ov. Met. 2, 325-327) «Наяди ... віддали тіло могилі $i$ надписали на камені віри: «Тут лежить Фаетон, візничий батьківської колісниці ...».

Подібно до дієслів-гіперонімів гіпоніми займають будь-яке положення стосовно прямої мови, однак найпоширенішою є препозиція (30 випадків, 46 \%). Друге і третє місце належить інтер- і постпозиції, відповідно, 19 (29\%) та 16 випадків (25\%).

Актуальні проблеми мовознавства [Актуальные проблемы языкознания] (C) Чернюх Б. В. [Чернюх Б. В.], cherboh@gmail.com Маркери прямої мови у римській поезії епохи Августа (на матеріалі "Метаморфоз" Овідія) [Маркеры прямой речи в римской поэзии эпохи Августа (на материале «Метаморфоз» Овидия)] (Українською / На укр. яз.) 


\section{3. Іменні та прономінальні фрази}

Окрім згаданих вище виключно дієслівних засобів пряму мову у аналізованих поемах впроваджують іменні та прономінальні фрази представлені: а) іменником або вказівним займенником; б) поєднанням іменника $з$ дієсловами, які не належать до verba dicendi.

Перший випадок зустрічається зрідка, становлячи собою еліптичні конструкції, у яких домислюються гіпероніми на зразок dicere напр.:

1 a) Cum sic Aesonides: 'o cui debere salute // confiteor, coniunx ... (Ov. Met. 7, 164-165) «Коли так (промовив) Ясон: «О дружино, якій, визнаю, завдячую порятунком ...».

1 б) At illa: //'Somne, quies rerum ... // pax animi, quem cura fugit ... (Ov. Met. 11, 622-624) «А вона: «Сне, спочинку речей, ... мире душі, від якого втікає турбота ...».

Значно частіше у поєднанні 3 дієсловом виступають іменники пов'язані $з$ актом комунікації. Найчастіше такими іменниками $є$ os: ora solvit (Ov. Met. 1, 181; 15, 73-74 / moverat (Ov. Met. 5, 332) / conpellat / ediditore (Ov. Met. 3, 143; Met. 8, 703; 12, 577); vox: voces reddidit (Ov. Met. 2, 691)/dedit (Ov. Met. 9, 574), voces addere (Ov. Met. 13, 578) / emittere (Ov. Met. 15, 561), iterabat/monuit vocibus (Ov. Met. 3, 494; 9, 669), committit voce (Ov. Met. 5, 305), vocem movit (Ov. Met. 10, 143); verbum: addidit/edidit / reddit verba (Ov. Met. 3, 183; 8, 751; 9, 21), verba incidere ceris (Ov. Met. 9, 528). Крім них також засвідчені dictum: resecuta est / conpellat dictis (Ov. Met. 6, 36; 8, 780), sors: sortem dedit (Ov. Met. 1, 375), carmen: subiungit carmina nervis (Ov. Met. 5, 338), sonus: editus sonus est (Ov. Met. 8, 767), questus; effundit questus (Ov. Met. 9, 367), iudicium: iudicium superis aperit (Ov. Met. 8, 703). Сказане, звичайно, не виключає й інших контекстів, у яких можуть уживатися згадані іменники, зокрема їх абсолютного вживання або поєднання із дієсловами мовлення.

Характерною ознакою цієї групи маркерів $\epsilon$ їх препозиція прямій мові. Постпозиція представлена єдиним випадком (Neleius ediditore (Met. 12, 542-577), поєднуючись із вжитим у препозиції ad haec Pylius.

Здійснений аналіз дозволяє констатувати, що домінуючим засобом впровадження прямої мови у «Метаморфозах» Овідія є дієслова мовлення, зокрема, гіпероніми, які лише констатують факт «говоріння»- dico, aio, inquam, fari. Першість серед них належить dico та aio. На противагу до них

Actual Problems of Linguistics [Aktual'ni problemy movoznavstva] (C)Cherniukh B. V. [Chernjuh B.V.], cherboh@gmail.com Markers of the Direct Speech in Roman Poetry of the Augustan Period (on "Metamorphoses" by Ovid) [Markery prjamoi' movy u ryms'kij poezii' epohy Avgusta (na materiali "Metamorfoz" Ovidija)] (in Ukrainian) 
inquam, яке вважається спеціалізованим засобом впровадження прямої мови, зустрічається значно рідше. Окрім згаданих дієслів, пряму мову також впроваджують дієслова мовлення 3 додатковими семантичними відтінками, серед яких найчастотнішими є clamo та його дериват exclamo, та іменними або прономінальними фразами. Як і у прозі, в аналізованому творі маркери прямої мови займають різне положення стосовно прямої мови, однак характерним $є$ розташування базових дієслів dico та aio переважно у інтрапозиції, тоді як для гіпонімів та іменних i про номінальних фраз властивішою $є$ препозиція. На відміну від прозових текстів, де переважає препозитивне вживання маркерів прямої мови, у «Метаморфозах» вони переважно вжиті в інтрапозиції. Причина цього найвірогідніше полягає в особливостях поетичного синтаксису, який, підпорядковуючись вимогам розміру, допускає вільніший порядок слів. Однак тут спостерігається різка відмінність у розташуванні дієслівних і недієслівних засобів і виразна тенденція останніх до розташування на початку.

\section{Література:}

1. Baños Baños, J. M. El discurso indirecto. [in:] Sintaxis dellatín clásico (Madrid, Liceus 2009): 733-758.

2. Bonami, O., Godard, D. «On the Syntax of Direct Quotation in French.» 15 th International Conference on HPSG (Stanford, 2008): 358-377, https://halshs.archives-ouvertes.fr/halshs-00751080.

3. Buchstaller, I. Quotatives. New Trends and Sociolinguistic Implications (Oxford, 2014).

4. Capone, A. «The pragmatics of quotation, explicatures and modularity of mind.» Pragmatics and Society 4/3 (2013): 259-284.

5. De Vries, M. The representation of language within language: a syntacticopragmatic typology of direct speech. Studia Linguistica 62/1 (2008): 39-77.

6. Deutscher, G. «The Grammaticalization of Quotatives.» The Oxford Handbook of Grammaticalization (New York: Oxford University Press, 2001): 646-655.

7. Fruyt, M. «Le discours indirect en diachronie: l'évolution du réfléchi indirect en latin.» Revue de Linguistique Latine du Centre Alfred Ernout De Lingua Latina 10/2 (2015): 1-31.]

8. Gayno, M. «Les modalités d'insertion du discours direct en latin tardif: bornage et redondance.» Revue de Linguistique Latine du Centre Alfred Ernout

Актуальні проблеми мовознавства [Актуальные проблемы языкознания] (C) Чернюх Б. В. [Чернюх Б. В.], cherboh@gmail.com Маркери прямої мови у римській поезії епохи Августа (на матеріалі "Метаморфоз" Овідія) [Маркеры прямой речи в римской поэзии эпохи Августа (на материале «Метаморфоз» Овидия)]

(Українською / На укр. яз.) 
De Lingua Latina 11 (2015), http://lettres.sorbonne-universite.fr/IMG/pdf/ DLL_11_M-Gayno.pdf].

9. Golato, A. «An innovative German quotative for reporting on embodied actions: Und ich solund er so 'and I'm like/and he's like'.» Journal of Pragmatics 32 (2000):29-54.

10. Güldemann, T. «When "say" is not day: The Functional Universality of the Bantu Quotative Marker ti with Special Reference to Shona.» Reported Discourse: A Meeting Ground for Different Linguistic Domains (Amsterdam: John Benjamins, 2002): 253-288.

11. Güldemann, T. Quotative indexes in African languages: A synchronic and diachronicsurvey (Berlin, New York, 2008).

12. Heine, B. «Grammaticalization.» The Handbook of Historical Linguistics (Oxford: Blackwell, 2003): 575-601.

13. Keizer, E. «The interpersonal level in English: Reported speech.» Linguistics, 47/4 (2009): 845-866.

14. Kieckers, E. «Zum ,pleonastischen“ inquit.» Glotta 10/3 (1919): 200-209.

15. Klamer, M. «How report verbs become quote markers and complementisers.» Lingua 110 (2000): 69-98.

16. Mikulová, J. «Verbs Introducing Direct Speech In Late Latin Texts.» GraecoLatina Brunensia 20/2 (2015): 123-143.

17. Mikulová, J. «Marking the End of Direct Speech in Late Latin.» Graeco-Latina Brunensia 21/2 (2016): 169-182.

18. Mikulová, J. «Direct Speech And Diversity Of Voices In Selected Letters Of Cicero To Atticus I (Direct Speech).» Studia Linguistica Universitatis Iagellonicae Cracoviensis 135 (2018): 201-209.

19. Romaine, S., Lange, D. «The Use of like as a Marker of Reported Speech and Thought: A Case of Grammaticalization in Progress.» American Speech 66/3 (1991): 227-279.

20. Rosén, H. «About non-direct discourse: Another look at its parameters in Latin.» Journal of Latin Linguistics 12/2 (2013): 231-263.

21. Sznajder, L. «Interférences et conflits dans les formes du discours indirect.» Theory and description in Latin linguistics: selected papers from the XIth International Colloquium on Latin Linguistics, Amsterdam, June 24-29, 2001 (Amsterdam: J. C. Gieben, 2002): $361-377$.

22. Sznajder, L. «Segments introducteurs de discours direct et repérages énonciatifs en latin biblique: éléments pour une étude diastratique et diachronique.» Revue de Linguistique Latine du Centre Alfred Ernout De Lingua Latina 11 (2015).

Actual Problems of Linguistics [Aktual'ni problemy movoznavstva] (C)Cherniukh B. V. [Chernjuh B.V.], cherboh@gmail.com Markers of the Direct Speech in Roman Poetry of the Augustan Period (on "Metamorphoses" by Ovid) [Markery prjamoi' movy u ryms'kij poezii' epohy Avgusta (na materiali "Metamorfoz" Ovidija)] 
23. Thomas, J.-F. «De la narration au discours rapporté dans l'épopée : le cas de l'Énéide.» Revue de Linguistique Latine du Centre Alfred Ernout De Lingua Latina 10 (2015), http://lettres.sorbonne-universite.fr/IMG/pdf/DLL_10_J-FThomas.pdf].

24. Vandelanotte, L. «Deixis and grounding in speech and thought representation.» Journal of Pragmatics 36 (2004): 489-520.

25. Vandelanotte, L. «Quotative go and be like: Grammar and grammaticalization.» Quotative: Cross-Linguistic and Cross-Disciplinary Perspectives (Amsterdam: John Benjamins, 2012): 173-202.

\section{References:}

26. Baños Baños, J. M. El discurso indirecto. [in:] Sintaxis dellatín clásico (Madrid, Liceus 2009): 733-758.

27. Bonami, O., Godard, D. «On the Syntax of Direct Quotation in French.» $15^{\text {th }}$ International Conference on HPSG (Stanford, 2008): 358-377, https://halshs.archives-ouvertes.fr/halshs-00751080.

28. Buchstaller, I. Quotatives. New Trends and Sociolinguistic Implications (Oxford, 2014).

29. Capone, A. «The pragmatics of quotation, explicatures and modularity of mind.» Pragmatics and Society 4/3 (2013): 259-284.

30. De Vries, M. The representation of language within language: a syntacticopragmatic typology of direct speech. Studia Linguistica 62/1 (2008): 39-77.

31. Deutscher, G. «The Grammaticalization of Quotatives.» The Oxford Handbook of Grammaticalization (New York: Oxford University Press, 2001): 646-655.

32. Fruyt, M. «Le discours indirect en diachronie: l'évolution du réfléchi indirect en latin.» Revue de Linguistique Latine du Centre Alfred Ernout De Lingua Latina 10/2 (2015): 1-31.]

33. Gayno, M. «Les modalités d'insertion du discours direct en latin tardif: bornage et redondance.» Revue de Linguistique Latine du Centre Alfred Ernout De Lingua Latina 11 (2015), http://lettres.sorbonne-universite.fr/IMG/pdf/ DLL_11_M-Gayno.pdf].

34. Golato, A. «An innovative German quotative for reporting on embodied actions: Und ich so/und er so 'and I'm likeland he's like'.» Journal of Pragmatics 32 (2000):29-54.

35. Güldemann, T. «When "say" is not day: The Functional Universality of the Bantu Quotative Marker ti with Special Reference to Shona.» Reported Discourse: A Meeting Ground for Different Linguistic Domains (Amsterdam: John Benjamins, 2002): 253-288.

Актуальні проблеми мовознавства [Актуальные проблемы языкознания] (C) Чернюх Б. В. [Чернюх Б. В.], cherboh@gmail.com Маркери прямої мови у римській поезії епохи Августа (на матеріалі "Метаморфоз" Овідія) [Маркеры прямой речи в римской поэзии эпохи Августа (на материале «Метаморфоз» Овидия)] 
36. Güldemann, T. Quotative indexes in African languages: A synchronic and diachronicsurvey (Berlin, New York, 2008).

37. Heine, B. «Grammaticalization.» The Handbook of Historical Linguistics (Oxford: Blackwell, 2003): 575-601.

38. Keizer, E. «The interpersonal level in English: Reported speech.» Linguistics, 47/4 (2009): 845-866.

39. Kieckers, E. «Zum ,pleonastischen“ inquit.» Glotta 10/3 (1919): 200-209.

40. Klamer, M. «How report verbs become quote markers and complementisers.» Lingua 110 (2000): 69-98.

41. Mikulová, J. «Verbs Introducing Direct Speech In Late Latin Texts.» GraecoLatina Brunensia 20/2 (2015): 123-143.

42. Mikulová, J. «Marking the End of Direct Speech in Late Latin.» Graeco-Latina Brunensia 21/2 (2016): 169-182.

43. Mikulová, J. «Direct Speech And Diversity Of Voices In Selected Letters Of Cicero To Atticus I (Direct Speech).» Studia Linguistica Universitatis Iagellonicae Cracoviensis 135 (2018): 201-209.

44. Romaine, S., Lange, D. «The Use of like as a Marker of Reported Speech and Thought: A Case of Grammaticalization in Progress.» American Speech 66/3 (1991): 227-279.

45. Rosén, H. «About non-direct discourse: Another look at its parameters in Latin.» Journal of Latin Linguistics 12/2 (2013): 231-263.

46. Sznajder, L. «Interférences et conflits dans les formes du discours indirect.» Theory and description in Latin linguistics: selected papers from the XIth International Colloquium on Latin Linguistics, Amsterdam, June 24-29, 2001 (Amsterdam: J. C. Gieben, 2002): $361-377$.

47. Sznajder, L. «Segments introducteurs de discours direct et repérages énonciatifs en latin biblique: éléments pour une étude diastratique et diachronique.» Revue de Linguistique Latine du Centre Alfred Ernout De Lingua Latina 11 (2015).

48. Thomas, J.-F. «De la narration au discours rapporté dans l'épopée : le cas de l'Énéide.» Revue de Linguistique Latine du Centre Alfred Ernout De Lingua Latina 10 (2015), http://lettres.sorbonne-universite.fr/IMG/pdf/DLL_10_J-FThomas.pdf].

49. Vandelanotte, L. «Deixis and grounding in speech and thought representation.» Journal of Pragmatics 36 (2004): 489-520.

50. Vandelanotte, L. «Quotative go and be like: Grammar and grammaticalization.» Quotative: Cross-Linguistic and Cross-Disciplinary Perspectives (Amsterdam: John Benjamins, 2012): 173-202.

Actual Problems of Linguistics [A $\overline{\text { ktual'ni problemy movoznavstva] }}$ (C)Cherniukh B. V. [Chernjuh B.V.], cherboh@gmail.com Markers of the Direct Speech in Roman Poetry of the Augustan Period (on "Metamorphoses" by Ovid) [Markery prjamoi' movy u ryms'kij poezii' epohy Avgusta (na materiali "Metamorfoz" Ovidija)] 